\title{
Improving Academic Writing Skills through Contextual Teaching Learning for Students of Bosowa University Makassar
}

\author{
Syahriah Madjid $^{1)}$, Emzir $^{2)}$, Sabarti Akhadiah ${ }^{3)}$ \\ ${ }^{1)}$ Bosowa University of Makassar, Makassar, Indonesia \\ E-mail:nani.mjd@gmail.com \\ ${ }^{2)}$ Universitas Negeri Jakarta, Jakarta, Indonesia \\ E-mail:emzir.pb@gmail.com \\ ${ }^{3)}$ Universitas Negeri Jakarta, Jakarta, Indonesia \\ E-mail: sabartiakhadiah@yahoo.com
}

\begin{abstract}
The purpose of this research is for helping students to improve their academic writing skills by changing the existing strategies which were considered ineffective at solving this kind of problem. This research was about how to improve student's academic writing skills through contextual teaching and learning. The clientele of this research was the students of Civil Engineering Department of Bosowa University of Makassar. To gain the final result in this research there are three periods were needed. The result for the first period is only $26.67 \%$ or only 8 from 30 students could pass the standard qualifying. The students which passed the standard qualifying becomes $80 \%$ from 30 students in next period and in the final period the result was already succeeded, all of the students could pass the standard qualifying. Those experiments prove that this research showed that contextual teaching and learning effects can be used in helping students improve their academic writing skills. This research recommends the lecturer to conduct intensive training in the process of planning to write, the evaluation of sources of references, and the development of writing based on academic writing strategy.
\end{abstract}

Keywords: Academic writing; Contextual Teaching Learning (CTL); Action Research

\section{INTRODUCTION}

In the academic life of lectures, writing is one of the conditions that must be done by the students. Not just connect words with words or sentences with sentences, but also write can convey information and ideas clearly. Find ideas, give meaning and put it in writing.

Writing activities are an integral part of the entire learning process experienced by students during their studies in universities. In addition, students are required to create an academic paper in the form of a thesis to earn their degree.

Related to that, the Director General of Higher Education issued a circular no. 152 / E / T / 2012 on the publication of scientific papers, among which are for graduate scholars should produce papers published in scientific journals on the grounds that the number of scientific papers from colleges is very low. Thus, they are expected to have a deeper ability to put their ideas or ideas into writing.
In addition, writing activities require skills that students sometimes lack. There is even a group of students who doubt its usefulness especially if the activities of writing is associated with a subject that is not a subject of study. Though the ability to write, especially in the form of academic papers that is the spearhead of the critical success of students in undergoing important processes in learning.

The ability to write a scientific work (academic) is a competence that must be owned by students as candidates scholars. Thus the activities of writing scientific papers are an integral part of the scholarship students activity.

The improvement of students' academic writing ability can be achieved well if he understands and employs it because writing skill is not an automatically acquired ability but must go through a learning process. As Lorch reveals that writing skills are not talent, nor innate, but possessed through continuous training. According to Rahayu writes are complex activities that are realized in a writing process 


\section{Academic Paper}

According to Sundara Raja, academic writing is a paper that tries to explain a scientific discussion conducted by a writer or researcher, with the aim of telling things logically and systematically to the readers. This academic paper is usually written to search for answers about something that is and to prove the truth about something contained in the object of writing.

Academic writing or known scientific paper is the writing that is done scientifically or scientifically. The Decree of the Coordinating Minister for the Supervision and Use of State Apparatus Number 38 / KEP / MK.WASPAN / 8/1999, CHAPTER I Article 1 Item 9 defines academic works as scientific papers that follow rules, rules and thoughts generally accepted in the sciences knowledge and scientific contribution that is eligible to be accepted and published in various journals both nationally and internationally, has its own format to be followed by every scriptwriter.

According to Monippally and Pawar, academic writing is defined broadly as a way of communicating science. It is generally aimed at scholars and other readers who are familiar with the science of knowledge.

Teuku Alamsyah also said in his book that a scientific paper can also be said to be a written report describing the results of research or study, whether conducted by a person or team that meets the scientific principles and ethics established and adhered to by the scientific community. Writing scientific work means generating a scientific mind in which reflects the nature of science. Characteristics of scientific writing, among others: the content reflects the nature of science/object of a particular science, contains the theory/framework of thinking, the method, and contain reasoning. This is confirmed by Alamsyah that the characteristics of academic writing are as follows: (1) is a discussion of a research result (factual objective), meaning the facts according to the studied premises, (2) methodical and systematic, meaning in the discussion of problems used certain methods with orderly and orderly controlled steps, (3) scientific writings using the scientific barrel, meaning the barrel of the scientific language used raw and formal. In addition, the scientific language barrel is straightforward and unambiguous.

Sidjiman and Sugono suggested that the scientific work is a paper whose compilation is based on scientific study. Through scientific work to be submitted observation (observation), experiment (experiment), research or literature study. Submission is done by using language media. The language used to convey the results of observations, experiments, research and literature study is a variety of writing. The writing variety of scientific papers should be clear, straightforward, and communicative so readers can easily understand the contents.

Contextual Teaching Learning
According to Johnson, Contextual Teaching and Learning is a learning system based on the philosophy that students are able to absorb lessons when they capture meaning in the academic material they receive, and they grasp meaning in schoolwork if they can associate information new with the knowledge and experience they already had before.

The awareness of the need for a contextual approach to learning is based on the fact that most students are unable to relate what they learn to how it is utilized in real life. This is because the academic concept they acquire is something abstract, yet to touch the practical needs of their lives, both in the workplace and in society.

Depdiknas describes contextual learning as a holistic educational process and aims to motivate students to understand the meaning of learning materials by connecting the material with the context of their daily life so that students have knowledge/skills that can be flexibly applied (transferred) from one problem/context to other issues/contexts. The context in question concerns the personal, the cultural and the personal context.

Contextual Teaching and Learning Approach is a learning concept that helps teachers/lecturers connect the content of the material taught to the real world situation of the students, encourage and motivate the students to apply their knowledge to the daily life as family members and members of the community.

According to Suherman, contextual learning is learning that begins by taking (simulating, recounting, dialogue or questioning) events in the real world of daily life experienced by students then raised into the concept discussed. Along with that, Sabandar sees contextual learning as a concept of learning that helps teachers connect the content of teaching materials with real-world situations and their application in their lives as family members, citizens, and workers and is actively involved in the learning activities demanded in the lesson.

\section{RESEARCH METHOD}

This research generally aims to collect data related to efforts to improve the ability of academic writing Indonesian students majoring in Civil Engineering University Bosowa Students. This method of research includes the type of action research, which is a research method that emphasizes social practice, aims toward improvement, a cyclical process, followed by systematic discovery, reflective process, participatory, and determined by the implementer. In terms of addressing the learning problem, the way it is offered is through a contextual approach. In addition, this study also aims to collect data about how the process and learning outcomes in improving students' academic writing skills majoring in Civil Engineering University of Bosowa Makassar through a contextual approach.

This research was conducted at the Faculty of Engineering majoring in Civil Engineering University of 
Bosowa Makassar. This action research was conducted on the first semester students for the Indonesian language course. The time of this research is carried out for one semester by involving team consisting of researcher, lecturer of Indonesian language lecturer and collaborator. The reasons for the selection of places and subjects because the researcher is a lecturer of Indonesian subjects assigned in major Civil Engineering so that problems and difficulties of writing experienced by students have been recognized. In addition, Bahasa Indonesia is a compulsory subject in every study program at Bosowa University of Makassar, which one of the topics of discussion is scientific or academic writing. Furthermore, action research is a means of creating collaborative learning so that learning orientation is no longer carried out individually but on a team basis.

This action research is carried out for one semester, which starts from September 2011 to January 2012. The first month is used for field observation and makes learning planning using a contextual approach, then the next four months to intervene the action of the learning model. This intervention is done in three cycles. Each cycle consists of four meetings and one meeting is held once a week for 100 minutes. The last week is used for evaluation and reflection. However, since this research is also a qualitative research, the time spent in this study relies on observations and assessments to be achieved using the cycle. The cycle will stop if the indication used by success has been achieved. If it has not been reached, it will continue in the next cycle.

The action research design is referring to The Action Research Cycle proposed by Stephen Kemmis and Taggart ie planning, action, observing, reflecting, as follows.

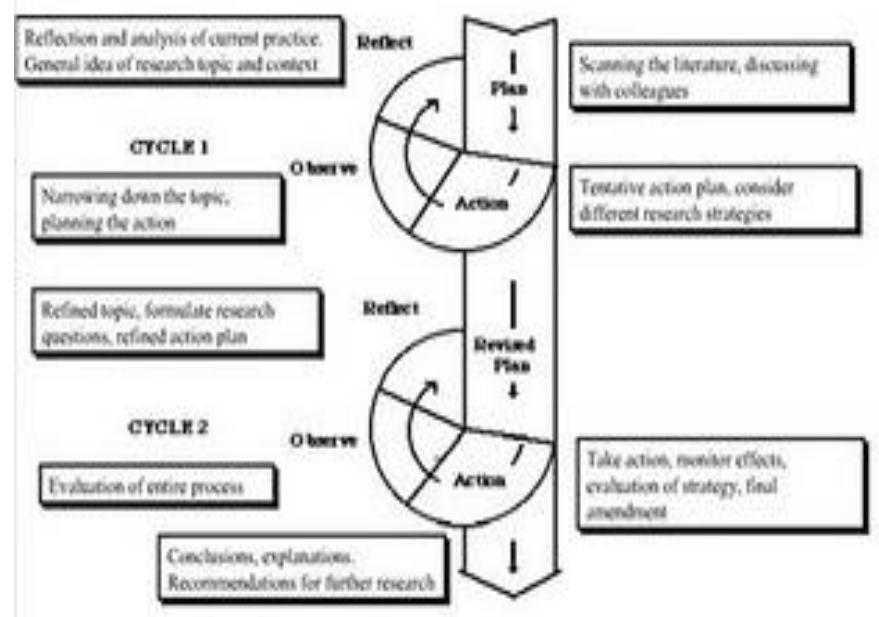

Fig. 1 The Action Research Cycle

In the research procedure this action used the research model which has been described in the research method consisting of planning action, doing the research (acting), doing observation from every research process (observing), reflecting the result of research with appropriate success criteria ( reflecting), and re-planning if the results are not in accordance with the criteria of success (replanning).

\section{Criteria for Action Success}

The success criteria of the study can be seen from the comparison of the previous value of giving action and after giving the action. Improvement of learning outcomes is considered successful if the value obtained by students reached an average score above 70 . In this study, the success of learning to write with contextual approach set the level of student satisfaction ability based on guidelines assessment of Bosowa University Makassar. The table of mastery levels can be seen below.

Table I

Guidelines for Academic Writing Capability

\begin{tabular}{|c|c|c|c|}
\hline Level of Mastery & Qualification & $\begin{array}{c}\text { Letter } \\
\text { Value }\end{array}$ & Score \\
\hline $80 \%-100 \%$ & Very good & A & 4 \\
\hline $70 \%-79 \%$ & Good & B & 3 \\
\hline $60 \%-69 \%$ & Average & C & 2 \\
\hline $50 \%-59 \%$ & Bad & D & 1 \\
\hline $0 \%-49 \%$ & Very bad & E & 0 \\
\hline
\end{tabular}

\section{RESULT AND DISCUSSION}

In this chapter will be presented data and research results of action research on improving the ability of academic writing through a contextual approach to students of the Faculty of Engineering, Department of Civil Engineering University of Bosowa Makassar. Implementation of this action research is carried out gradually over three cycles so that the focusing problem can be addressed and the research objectives are achieved. Each cycle consists of planning, action, observation, and reflection (planning, acting, observing and reflecting). The work of each student in the ability of academic writing through contextual learning obtained at the end of the learning in the form of academic writing products, namely in the form of papers.

The aspects assessed in developing the introduction include focusing on the reader's attention by introducing accurate and complete facts, as well as explaining the historical background that has a direct relationship to the problem to be discussed.

Furthermore, the aspects assessed in the development of the content are by developing on the basis of genus, definitions, examples, and causation, or also developing by means of authority, the opinions or sayings of a recognized person of expertise, or well-known.

The assessment aspect of the conclusion is the answer to the problem or refresh the reader's memory of what has been achieved. Based on the aspect of the assessment, then the discussion of academic writing products 
will be based on preliminary aspects, content aspects, conclusion aspects, and the aspects of references and writing techniques.

First Cycle

The result of academic writing ability through student contextual learning strategy in the final learning activity in this first cycle can be seen that (1) there is still no student who qualified with very good value, (2) Students who get good score is still 8 people or $26,67 \%$ of 30 students, (3) students who get qualified enough there are 18 people or $60 \%$ of 30 students, and (4) students who scored less still there are 4 people or $13.33 \%$ of 30 students, also (5) there is not a single student who scored very less.

When considering the provisions of the level of mastery of students guided by the guidance of the assessment of the university, set the level of mastery of students reach an average value of 70 , then it can be seen that from 30 students who expressed as many as 8 people or $26.67 \%$ more or equal to 70 . Thus, in terms of outcomes, the cycle I has not been declared successful because all students have not succeeded in achieving the targets that have been determined.

Based on the results of product assessment of each stage of academic writing through contextual learning, students' academic writing skills have not achieved the expected results. The results of the assessment of academic writing ability are grouped based on the composition of academic writing, namely introduction, content, conclusions, and bibliography. The results of reflection based on written products are described as follows. (1) In general, not all students can develop the introduction. Preliminary development generally only explains the historical background that has a direct relationship to the issue to be described, has not focused on the reader by introducing the facts presented, nor has it elaborated on why the selected topic is a problem. (2) The contents of writing have not been developed maximally and yet varied. It is generally developed with the support of a well-known or recognized expert opinion. This is understandable because the content must be supported by reference sources even though the reference source used is still limited. Other forms used in the development of written content through definitions and examples. (3) In conclusion, generally has not been addressed the issues described in the introduction although there are some that have missed the problem. In addition, some are developing conclusions rather than conclusions but are still the content of writing even though placed at the end of writing. (4) On reference/reference, generally does not include a reference list. There are also unsuitable references to the reference list. This is because students refer to the second source instead of the original.

Second Cycle

The result of academic writing ability through student contextual learning strategy at the end of learning activity in this second cycle can be seen that (1) there are 5 people or $16,67 \%$ from 30 students who get very good value,
(2) there are 19 out of 30 people or $63.33 \%$ of the qualified, (3) qualified and qualified students of 6 or $20 \%$ of the 30 students, and (3) none of the students qualify or less.

When considering the provisions of the level of mastery of the students' ability based on the assessment of Bosowa University of Makassar, set the level of mastery of students reaches an average value of 70 , thus it can be seen that from 30 students who expressed as many as 24 people or $80 \%$ or equal to 70 , and students who are declared unfinished as many as 6 people or $20 \%$ because it can not reach the value 70 . Thus, in terms of results, this cycle II cannot be declared successful because there are still some students who have not reached the target that has been determined, or the completeness has not reached $100 \%$.

Based on the results of product assessment from each stage of academic writing through contextual learning strategy, students' ability in academic writing still has not reached the expected result, therefore cycle II is not yet fully successful. The results of the assessment of academic writing ability are grouped based on the composition of the academic writings namely, introduction, content, and conclusions, as well as the referral list. The results of the assessment reflection of the academic writings of the students are described below. (1) Introduction developed by the students has begun to focus the reader's attention on introducing facts, but the facts used are still incomplete. Similarly, the introduction that reveals the background to the issues to be discussed is not sufficient. In addition, in the introduction there are still technical errors of writing include the use of inappropriate diction and inter-allegorical coherence and between paragraphs less cohesive a week preliminary formulation is not appropriate (2) Pengembangam content academic writings made by students have varied by using the opinion of a famous person or recognized expertise, is also equipped with development through examples, causes, and logical reasoning. However, development is still constrained by some technical errors in spelling, diction, and word writing. The most prominent of these errors is that they have not been able to distinguish between the preposition and the di- prefix. (3) In the development of conclusion, generally, students have been able to develop the conclusion of their academic writing by answering the problem and refreshing the reader's memory about what has been described. However, there is still a small percentage of students developing conclusions not yet completely and refreshing the reader's memory of what has been said, consequently the conclusions have not yet been representative of the content as a whole.

Third Cycle

The results of academic writing ability through the contextual learning strategy of the students from the final learning activity in cycle III can be seen that (1) There are 15 people or $50 \%$ of the 30 students who get the value of Good Once, (2) while 15 students get good grades, and (3) none of the students get enough, less or less. 
Judging by the provisions of the level of mastery of students guided by the assessment guidelines of the university, it can be seen that from 30 students who declared complete as many as 30 people or $100 \%$ because it has reached the value of more or equal to 70 . Thus, in terms of results, successful because all students managed to achieve the target that has been determined.

Based on the results of product assessment of each stage of academic writing through contextual learning strategies, the ability of students in academic writing has achieved the expected results, therefore Cycle III is declared to have succeeded. The results of the assessment of academic writing ability are grouped based on the composition of academic writings, namely, introduction, academic content, and conclusions.

\section{IV.CONCLUSIONS}

Based on the explanation and discussion, as well as reflections on the actions described earlier, a conclusion can be drawn as follows.

1. Improvement of students' ability in academic writing occurs periodically during cycle I, cycle II, until cycle III. In Cycle I students who managed to get good grades there are only 8 people or as much as $26.67 \%$ of a total of 30 students. In this cycle, students are still having difficulty in preparing good academic writing. Most of the students have not prepared the planning in developing academic writing. Lecturers must still assist in directing students in determining relevant reference sources and limiting the scope of topics about engineering sciences that are in accordance with the study program it is engaged in. This is because students are still lacking reading in order to deepen the initial knowledge possessed. In cycle II, there was an increase so that the number of qualified students with good grades increased to 24 people or $80 \%$ of the total students. In this cycle, the development of academic writing as a whole has begun to complete in accordance with the composition of academic writing. However, the drawback is that the students still lack the reference source data that can support the contents of the assigned academic paper. Data from the experimental results in cycle III shows that $100 \%$ of all students finally managed to get a value that meets the standard of success that is more than or equal to 70 . In this cycle, students are able to develop the concept of academic writing with good writing systematics. The mind map has already begun to outline the content of the discussion. References sources in the development of academic writing have already begun to complete.

2. Based on the observation of the researcher, and the reflection of learning by the students, as well as the series of data on the result of the assessment that has been done, it can be concluded that through contextual learning can improve the academic writing ability of the
Faculty of Engineering students of Civil Engineering Department of Bosowa University Makassar.

\section{REFERENCES}

Akhadiah, Sabarti, Maidar G. Arsyad, Sakura H.Ridwan. (1999). Pembinaan Kemampuan Menulis Bahasa Indonesia. Jakarta: Erlangga.

Alamsyah, Teuku. (2008). Bahasa Indonesia: MKU untuk Mahasiswa. Banda Aceh: FKIP Unsyiah.

Depdiknas. (2002). Pendekatan Kontekstual. Jakarta: Depdiknas.

Henuk, Yusuf Leonard. (2009). "Standar Penulisan Karya Ilmiah”, Kompas Kupang.com, Senin, 13 Februari 2012, 11.08 Wit.Johnson, Elaine B. PH.D., Contextual Teaching and Learning. Bandung: MLC.

Kamber, D. (2000). Action Learning Research Improving the Quality of Teaching and Learning. London: Page Limited.

Monippally, Mathukutty $\mathrm{M}$ and Badrinarayan Shankaar Pawar. (2010). Academic Writing: A Guide for Management Students and Researchers. New Delhi: Response Books.

Raja, Sivachandralingam S. (1999). "Penulisan Akademik: Pemikiran dan Penulisan Ilmiah di Universiti, kertas kerja yang disajikan pada bengkel fasilitator untuk modul Pengayaan Pembelajaran Pelajar Baru Sesi 1999/2000”, Fakultas Sastera \& Sains Sosial. Malaya: Universiti Malaya.

Sabandar, J. (2003). Pendekatan Kontekstual dalam Pembelajaran Matematika. Bandarlampung: FKIP Unila.

Sudjiman, Panuti, Dendy Sugono (1991). Petunjuk Penulis Karya Ilmiah. Jakarta: Kelompok 24 Pengajaran Bahasa Indonesia.

Suherman, Erman. (2003). Evaluasi Pembelajaran Matematika. UPI Bandung: JICA. 